of the Witwatersrand. Since 1925, Dr. Dart has discovered many specimens of a sub-human creature, Australopithecus prometheus. He postulated that this proto-man belonged to the hominid rather than the ape family, and that Africa, not Asia, was the birthplace of man. In 1955, Dr. Dart discovered Australopithecus buried with crudely-worked tools of a Pebble Culture. Dart's theory was thereby accredited and his find recognized as the most primitive creature known to date that can be called human. Dr. Griffin, director of the Museum of Anthropology and professor of anthropology at the University of Michigan, was cited by the Society for American Archæology for his great influence in promoting the aims of scientific archæology, and for his unsurpassed knowledge of the form, range and distribution of artefact styles in North America. Dr. Mead was selected as the 1957 medallist in general anthropology by the American Anthropological Association. She is associate curator of ethnology at the American Museum of Natural History, and has done more than any other single individual to introduce anthropology to the American public. A prolific writer, among Dr. Mead's most popular books are "Coming of Age in Samoa", "Growing Up in New Guinea", "Male and Female" and "Now Lives for Old".

The Viking Fund Medals and awards originated upon the suggestion of Dr. Axel L. Wenner-Gren, the Swedish industrialist who endowed the Foundation now bearing his name. Since 1946, the WennerGren Foundation has provided the medals and prizes of 1,000 dollars, which are awarded to the general anthropologist, archæologist and physical anthropologist who has made a significant contribution to his field.

\section{Train Control on Railways in Britain}

IN replying to a debate on automatic train control on March 7, on an adjournment motion moved by Mr. P. C. Goodhart, Mr. G. R. H. Nugent, Parliamentary Secretary to the Ministry of Transport and Civil Aviation, said that in the past 46 years, 698 formal inquiries had been made in Britain into rail accidents in which 1,599 people were killed. Of these accidents, automatic train control could probably have avoided 11 per cent and 31 per cent of the fatalities. Track circuiting is a further safety device which serves primarily to record that a train is in a particular sector of the track, and with colour light signals, which are easier to see, especially at night and in fog, and can be linked with automatic train control and track cir. cuits and the control board in the signal box, could make a big contribution to traffic safety but without eliminating the human element. Automatic train control was started on the initiative of the Great Western Railway in 1905, but the equipment of the main lines of Britain was not completed until 1930, and the non-contact magnetic Hudd system evolved in the 1930's and tried on the London, Midland and Scottish Railway was not finally approved by the Minister of Transport until 1947. In 1948, the British Transport Commission decided to make a wide extension of automatic train control, colour light signals and track circuits : the Great Western system was regarded as unsuitable for electrio lines and its heavy mechanized parts were unsuitable for permanent and universal adoption. The Commission is also convinced that a non-contact magnetic system superior to the Hudd system could be found; but although full-scale trials have been carried out since 1950 on the east coast line, as was expected, many difficulties were encountered. The routes carrying the greatest train frequency and speed would receive the earliest attention, and installation is in no way retarded by eapital restrictions.

\section{Millenary Celebrations of Al-Mas'udi}

THE millenary of Al-Mas'udi, the tenth century Arab geographer, traveller and encyclopædist, was recently celebrated at the Muslim University, Aligarh, under the joint auspices of the Institute of Islamic Studies, Aligarh, and the Indian Society for the History of Science. About thirty papers were received from all parts of the world, including Britain, Egypt, France, Holland, India, Iran, Lebanon and the United States

Mr. A. A. A. Fyzee, vice-chancellor of the University of Jammu and Kashmir, devoted his presidential address to the need for studies of the humanities in the university, particularly in view of the technological changes in progress in India. He stressed that the aim was not to produce theologians, which has been the dominant tendency in the past, "but to produce men of understanding and intelligence, of balanced judgment and critical appreciation of the past". Prof. M. S. Thacker emphasized the collaboration that had existed between the Arab countries and India in the search for knowledge. After giving a general survey of Al-Mas'udi's contribution in the field of science, he suggested the great need for a scientific study of the available material, particularly from the point of technology and its relation with the intellectual attainments of the age. Prof. N. Ziadeh discussed the geographical, climatological and certain social details of Sham (Syria) given by Al-Mas'udi, and Dr. M. Shafi dealt with his geographical contributions, particularly in the field of human geography, which Al-Mas'udi did much to establish on scientific lines. In a general survey of science at the time of Al-Mas'udi, Mr. A. Rahman emphasized its characteristic features, namely, its association with the concept of God as the driving force of the universe, and its relation to the Greek philosophical outlook. It is proposed that the contributions shall be published in the form of a commemorative volume.

\section{Society for Visiting Scientists}

THE report of the secretaries on behalf of the Council of the Society for Visiting Scientists to the tenth general meeting on December 19 records continued restriction, for financial ressons, of the Society's activities, although the Overseas Science Students' Association continues to flourish. The Society has now nesrly 2,900 members, from sixtyfive countries, but only one reception could be held during the year, for participants in the symposium of the Royal Astronomical Society and the Royal Meteorological Society on "Planetary Atmospheres and Convection in Rotating Fluids". The Society's information service is constantly growing, helped by generous gifts of periodicals and reference books, but only limited success attended an attempt to increase the income from industry. Five most successful discussion meetings were held during the year, desling respectively with "The Effects of Low Temperatures on Mammals and their Tissues" ; "The Widening Field of Application of Electronic Computers"; "Taste and Smell"; "Water Quality Problems in the United Kingdom" ; and "Science and Furniture". The lively discussion which characterized all the Society's meetings is further indication of the value of its 